\title{
PAISAGISMO E AS CENTRALIDADES URBANAS
}

Sérgio Marin de Oliveira

Arquiteto e paisagista, Superintendente de Paisagismo e Meio Ambiente da Empresa Municipal de Urbanização (EMURB) de 2001 a 2004.

E-mail:apui.ap@terra.com.br

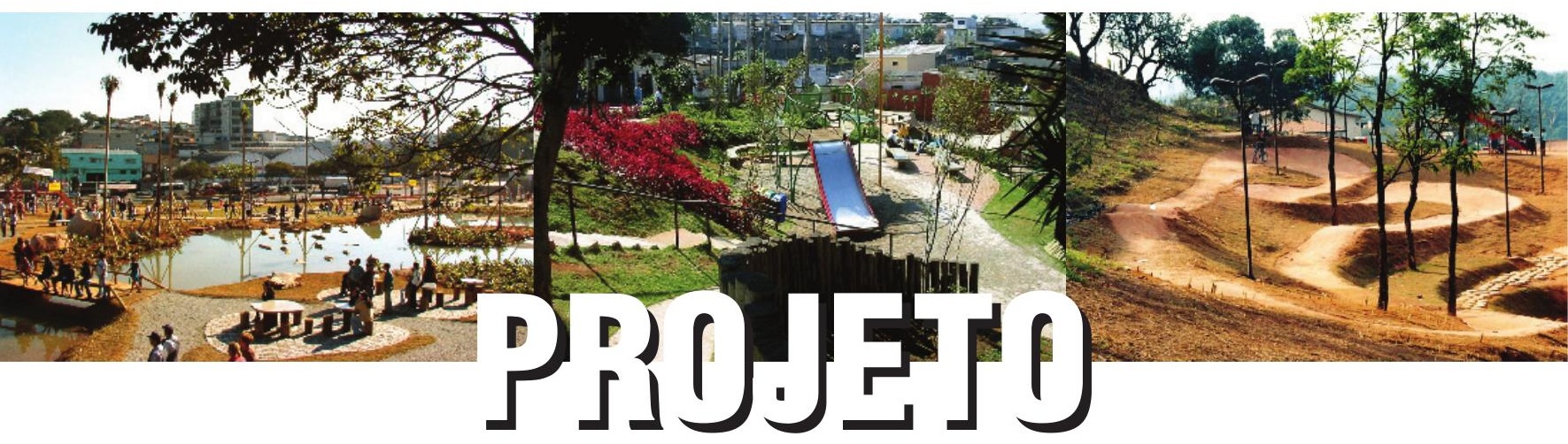




\title{
RESUMO
}

Este texto sobre o Programa de Centralidades Urbanas (Centros de Bairros) na cidade de São Paulo procura explicitar a importância que o projeto paisagístico teve em sua definição desde o início, destacando a relevância da questão ambiental em grandes centros urbanos.

Não se tratou de projetar de modo reparador, complementar, ou ainda, de intervenções pontuais. $O$ paisagismo, entendido em sua totalidade, foi mote e motor do programa.

Sua coordenação (projetos, procedimentos burocráticos, acompanhamento e fiscalização das obras) foi realizada pela Empresa Municipal de Urbanização (Emurb), com as secretarias municipais.

Palavras-chave: Questões ambientais, projeto paisagístico, políticas públicas.

\begin{abstract}
This paper focuses on the Centralidades Urbanas Program, which applied landscape concepts in several central areas within peripheral districts in the city of São Paulo (Brazil), considering important environmental issues in great urban centers.

It intends to explicit the landscape's importance since the program's initial definitions, and to demonstrate that, since then, it conceived landscape in the concept's plenitude, instead of being a complementary project which would develop punctual actions.

The Program Coordination (project development, bureaucratic procedures, monitoring, and work inspection) was carried out by Municipal Urbanization Company (Emurb) in partnership with other executive municipal bodies.
\end{abstract}

Keywords: Environmental issues, landscape architeture projects, urban policy. 


\section{PAISAGISMO E AS CENTRALIDADES URBANAS}

\section{Introdução}

A implantação do Programa de Centralidades Urbanas no município de São Paulo, desde o ano de 2002, retoma a questão da importância do projeto paisagístico e do paradigma ambiental como componentes da construção do espaço urbano, em particular, de cidades de complexa estrutura e desigualdades latentes.

A cidade de São Paulo, quer por sua dimensão quer por sua ocupação, muitas vezes predatória, sobretudo em sua periferia, apresenta contrastes de oferta de equipamentos públicos, de saneamento, infra-estrutura e de áreas qualificadas para uso coletivo.

Esses contrastes se estendem ao clima e ao meio ambiente. As diferenças de temperatura em um mesmo horário, em uma cidade do porte de São Paulo, são consideráveis, e os espaços distribuídos, também desigualmente, com grandes taxas de impermeabilização, dificultam o combate às intempéries naturais, causadoras de tormentoso cotidiano para a população.

Esse programa de urbanização de áreas carentes procura estudar e entender essas realidades e, na proporção possível, minimizar os efeitos, inclusive sociais, resultantes desse processo, pois, historicamente, pouco se fez ou se investiu nessas áreas. As demandas por melhorias tendem a aumentar, ano a ano, incrementando também as dificuldades para atendê-las e combatê-las.

O Programa de Centralidades Urbanas é uma experiência rica por operar com estruturas matriciais, trabalhando, simultaneamente, com várias secretarias municipais, com as subprefeituras, bem como ouvindo setores organizados da população.

Essa abordagem da ação multiplicadora e integrada a partir de diagnósticos locais, com possíveis participações dos próprios moradores e usuários, foi um de nossos pontos de partida.

\section{Objetivos e Estratégias}

O programa de implantação de Centralidades (Centros de Bairros) teve como objetivo fundante criar ambiências urbanas de vizinhança, em áreas públicas, 
nas regiões carentes da cidade de São Paulo, quer com equipamentos de lazer, esporte e cultura, quer como referência paisagístico-ambiental, prioritariamente para a comunidade moradora e freqüentadora dessas áreas.

A definição das 50 áreas contempladas (cerca de um milhão de metros quadrados) partiu da constatação e conhecimento de áreas de exclusão social na cidade, resultando, naturalmente, em sua quase totalidade, em ações nas regiões periféricas.

Tratou-se, em boa parte, de construir espaços referenciais, possibilitando convívio social entre freqüentadores de faixas etárias e disposições diferenciadas.

Esses projetos urbanos tentam abarcar interesses difusos e, muitas vezes, criam ou evidenciam tensões. Procurou-se agenciar espaços nos quais se realizavam atividades geradoras de ruídos (quadras de esporte, pistas de skate, etc.) com áreas de silêncio e contemplação (estares, mirantes). Isso exigiu negociações e acordos entre usuários e moradores, quanto a horários e atividades.

Para tanto, a proximidade com as subprefeituras foi fundamental. As áreas eleitas para o programa foram indicadas pelos subprefeitos, conhecedores da região e de seus problemas, a partir de critérios preestabelecidos.

A apreensão imediata desses espaços como direito conquistado é fundamental para o sucesso e multiplicação de ações. A ocupação do espaço público é um ato político que se desdobra no aprimoramento de organização, inclusive na participação da manutenção, tanto dos equipamentos quanto das áreas ajardinadas, garantindo sua integridade.

\section{Estruturação dos Trabalhos}

A dimensão das tarefas necessárias para a elaboração dos projetos, procedimentos gerenciais e burocráticos e a efetiva concreção em obras exigiu uma estruturação específica para o programa.

fator tempo também foi decisivo para a formatação e os encaminhamentos realizados. Foi montada uma equipe formada por arquitetos, paisagistas e engenheiros agrônomos, que participou tanto da elaboração dos projetos como no gerenciamento das obras.

Cada gerente de equipe ficou responsável, simultaneamente, por cerca de cinco a seis obras. $\bigcirc$ importante desse processo é que, muitas vezes, o projeto básico sofreu transformações durante a obra, agregando propostas de outros setores (como a construção de um posto policial), assim como as da própria população. Em alguns casos, acessos foram redefinidos e melhorias no entorno dos projetos iniciais concretizaram-se. 
Todos os projetos foram construídos com olhares múltiplos, tanto técnica como esteticamente.

\section{Projetos}

pedestre foi nosso alvo.

Todos os projetos procuraram valorizar o ato e a possibilidade de passear e flanar. Sem desmerecer ou deixar de atender adequadamente ao problema do trânsito de automóveis exigente de cuidados técnicos significativos, consideramos como prioridade o cidadão que caminha, que carece de espaços de lazer, que precisa de locais para descanso e encontros.

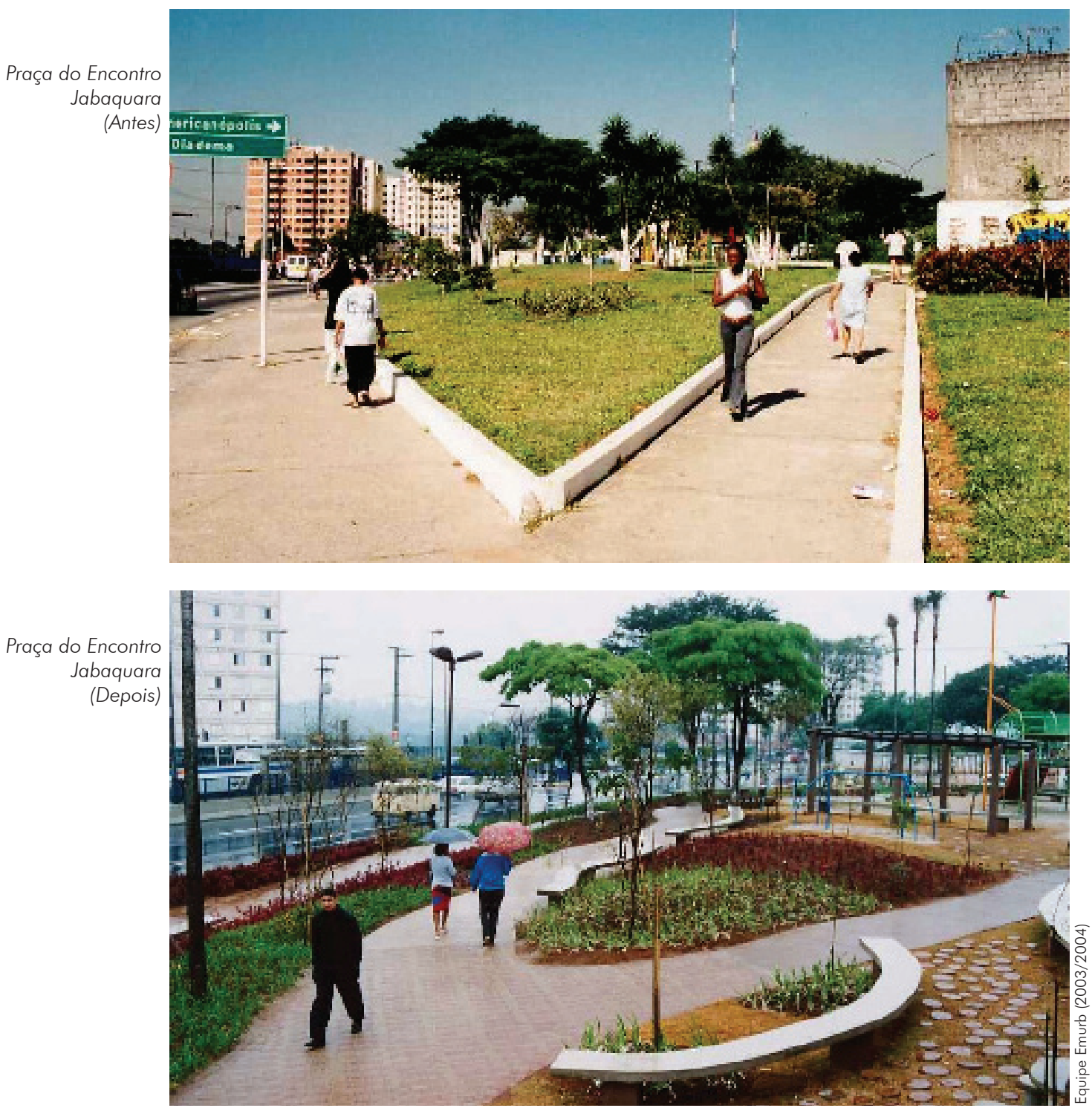


Com a Companhia de Engenharia de Tráfego (CET), foi pensada a segurança do pedestre, privilegiando-o, afastando-o do meio-fio, separando-o da pista de autos por meio de jardins. A indução para travessias somente nas faixas apropriadas fez parte da mesma preocupação. Ocorreram incompreensões advindas, talvez, do repertório visual e de usos consolidados. Em rotatórias, a supressão do piso em seu entorno, com o intuito de aumentar a segurança do pedestre, não foi imediatamente entendida por setores da população. Mas não há regra geral ou leituras comuns - enquanto no Largo de São Mateus, na zona leste da cidade, a novidade foi absorvida sem dificuldades; por outro lado, no projeto do Largo de Vila Prudente, recebemos muitos questionamentos. As duas áreas ofereciam grande perigo de circulação, devido ao trânsito pesado e às travessias irregulares (sempre às pressas) dos munícipes.

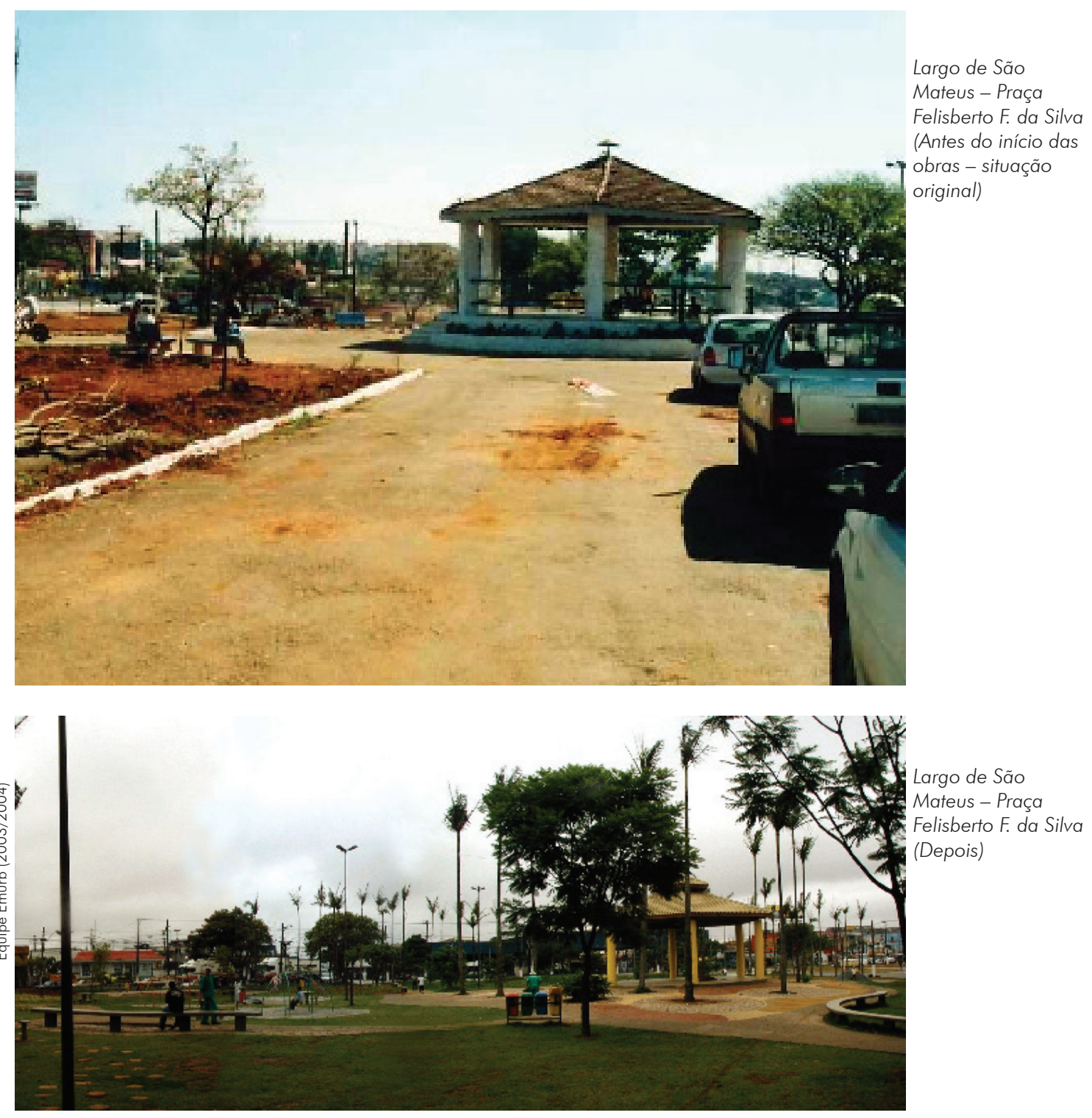


projeto urbano renovador tem de apoiar-se nas experiências acumuladas, discutindo com o cidadão novas possibilidades a partir de repertórios assimilados. A degradação desses espaços, aliada ao receio e à insegurança da população, fizeram com que houvesse um abandono dessas áreas públicas, fato esse que aprofundou essas mesmas degradações. A degradação se auto-alimenta e a sensação, real ou não, de descuido e de violência possível e iminente, amplia-se.

Enquanto os edifícios e condomínios de classe média isolam-se do espaço externo, representante de carências e perigos, substituindo os espaços públicos por área de lazer e diversão dentro do próprio empreendimento (motivado por exigências de taxas de ocupação e coeficientes de aproveitamento e, de qualquer forma, majorando seu valor comercial), os agrupamentos humanos empobrecidos, menos abonados, ficam excluídos dessa possibilidade. Não Ihes resta saída fora do espaço público.

Esse fato, obviamente, não é recente. Em A cidade e a criança (1989), Mayumi Souza Lima, na página 90, afirma a respeito das cidades pré-industriais: " $A$ rua é de tal forma ligada à habitação que não se distingue onde começa o espaço privado e onde termina o espaço público." Em seguida caracteriza "os espaços privados como exíguos, nos quais adultos e crianças de diferentes idades se acotovelavam e, entre esses espaços privados e os espaços públicos abertos, existia uma gradação de lugares que uniam o indivíduo e a sociedade, a família e o urbano".

Mais adiante, na página 92, questiona: "Para reconstruir a unidade das relações afetivas, psíquicas e cognitivas que the assegure simultaneamente a individualidade e a socialização, a criança terá de encontrar nas novas condições urbanas aqueles espaços permeáveis onde seja possível os jogos e as brincadeiras que envolvam os companheiros da mesma idade e observar o mundo dos adultos. Que espaços são esses nas cidades modernas?."

Verificou-se a impressionante demanda que a cidade propicia: equipamentos de lazer e esportes são utilizados dia e noite. Foram construídas cerca de 30 pistas de skate e não param de surgir meninos e meninas dispostos a exercitar-se e entreter-se. Esse entretenimento produz vida organizada, diálogo e convívio social.

Quando foram eliminadas ruas de trânsito intenso que separavam escolas e creches de um "Centro de Bairro" (praça Wilson Moreira da Costa - Butantã), integrando, espacialmente, equipamentos públicos, reduziu-se a zero a possibilidade de atropelamentos. Foram construídas pequenas praças sombreadas com bancos para as mães e parentes aguardarem a saída das crianças, gerando a oportunidade de contato e novos conhecimentos. 
Tais projetos auxiliam, efetivamente, o combate à violência urbana. Há informações que referendam essa tese, como, por exemplo, o Centro de Bairro, localizado em Parada de Taipas, local com histórico de violência, o qual teve forte diminuição de casos policiais a partir do uso da área.

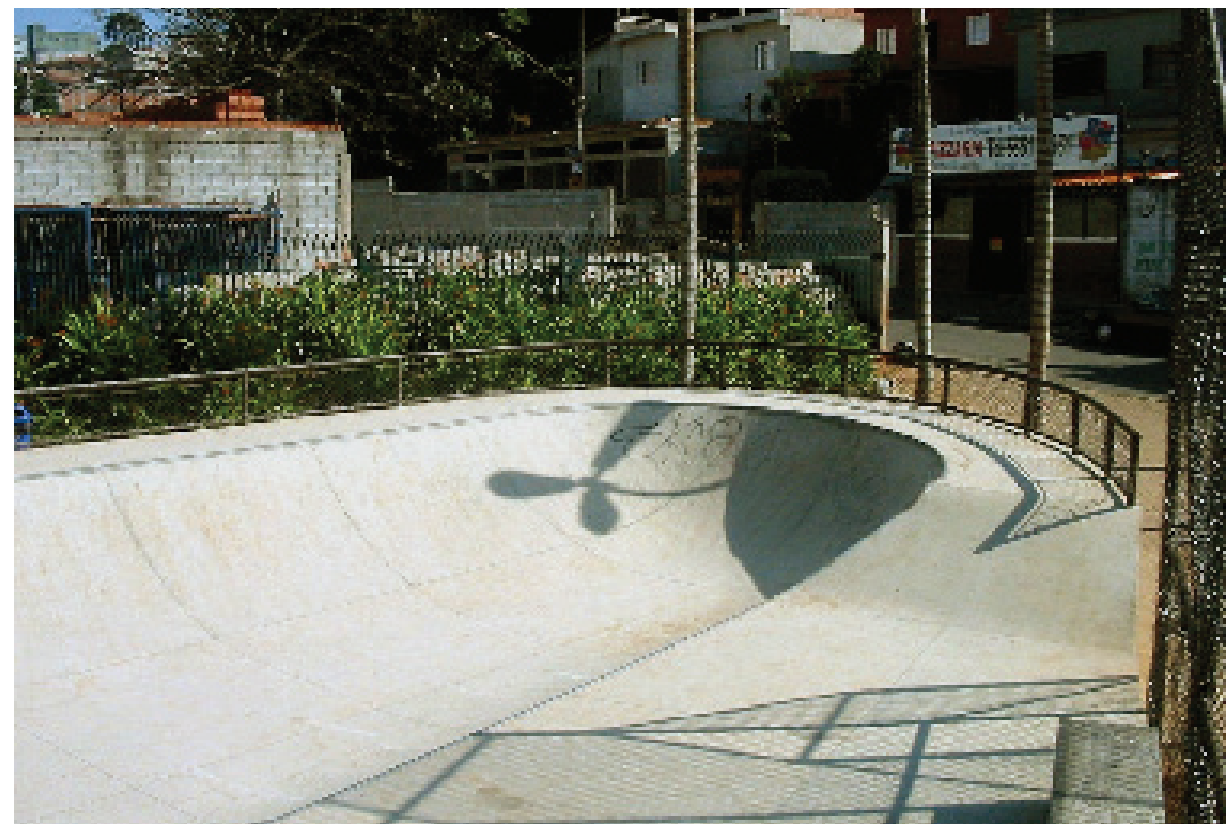

Equipamentos

públicos - pistas de skate

Feirão São Luis

Esses fatos se dão pelo uso intensivo dos equipamentos, tais como as já citadas pistas de skate, quadras poliesportivas, playgrounds, pistas de cooper e caminhada, estares, mirantes, palcos cobertos e descobertos para eventos culturais, mas também pela instalação de iluminação apropriada, com postes baixos, sob as copas das árvores, garantindo a visibilidade e transparência que o desenho dos passeios e o projeto paisagístico procuram.

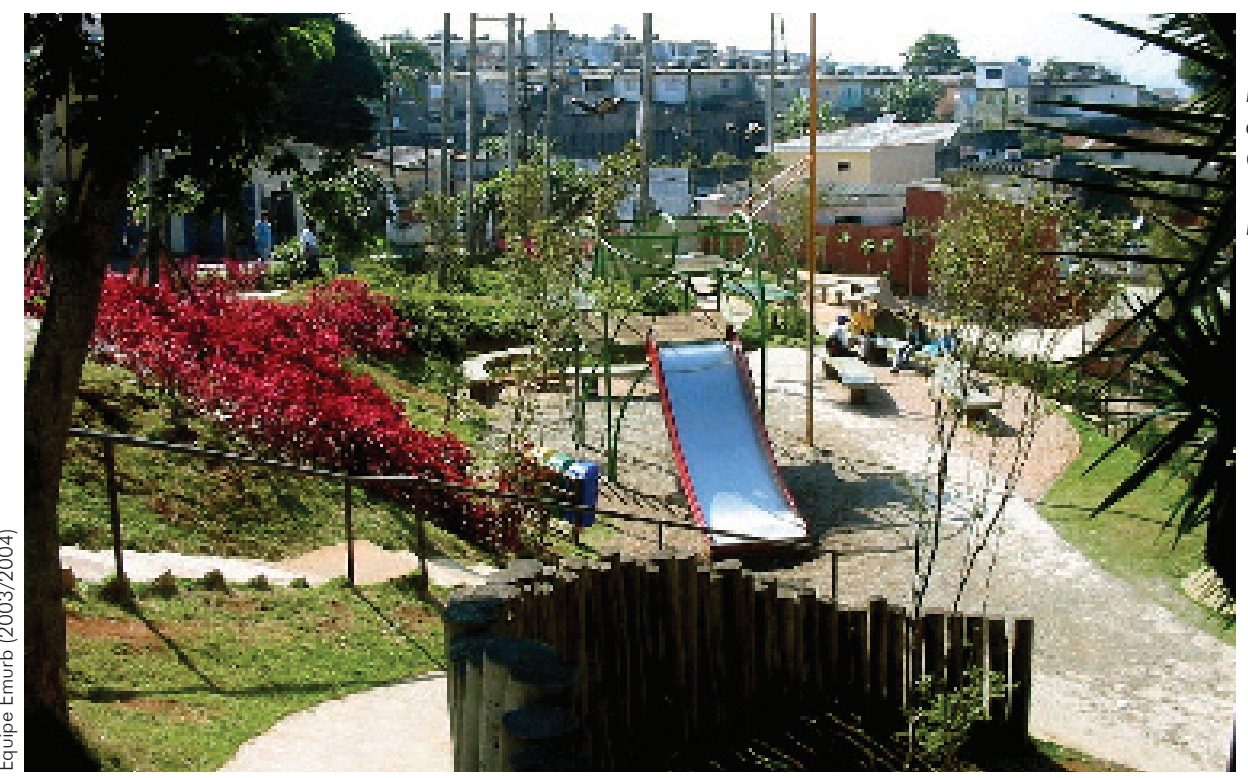

Praça Santo Dias

da Silva

Campo Limpo

Em janeiro de 2003 
Equipamentos públicos Pergolado e brinquedos Praça do Encontro

Equipamentos públicos Pergolado e brinquedos

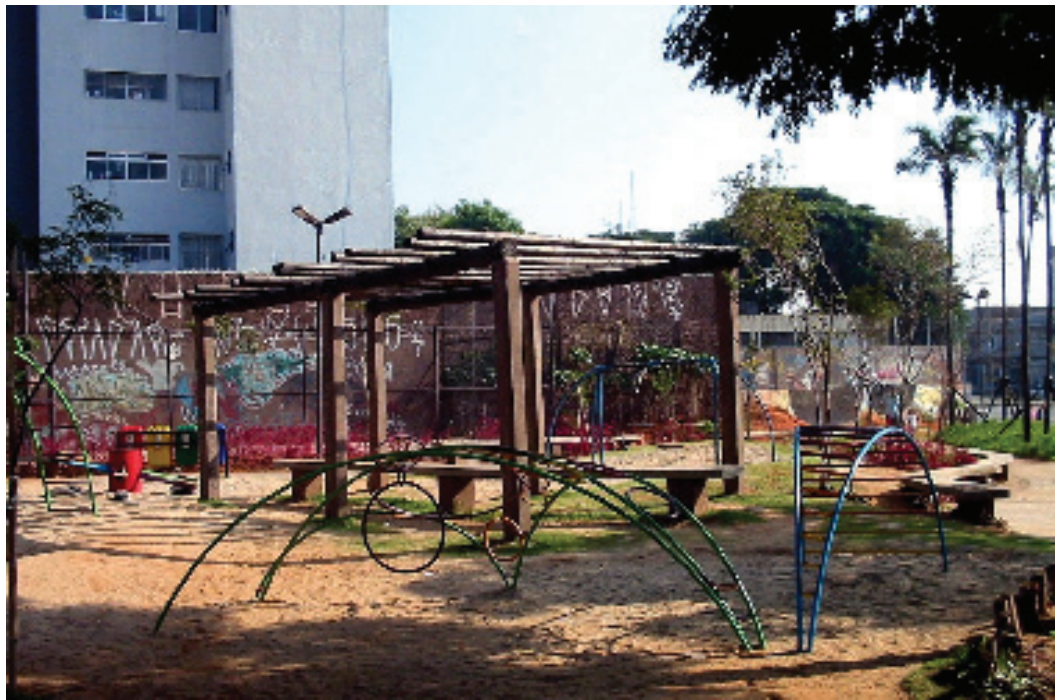

Av. Armando de Arruda Pereira

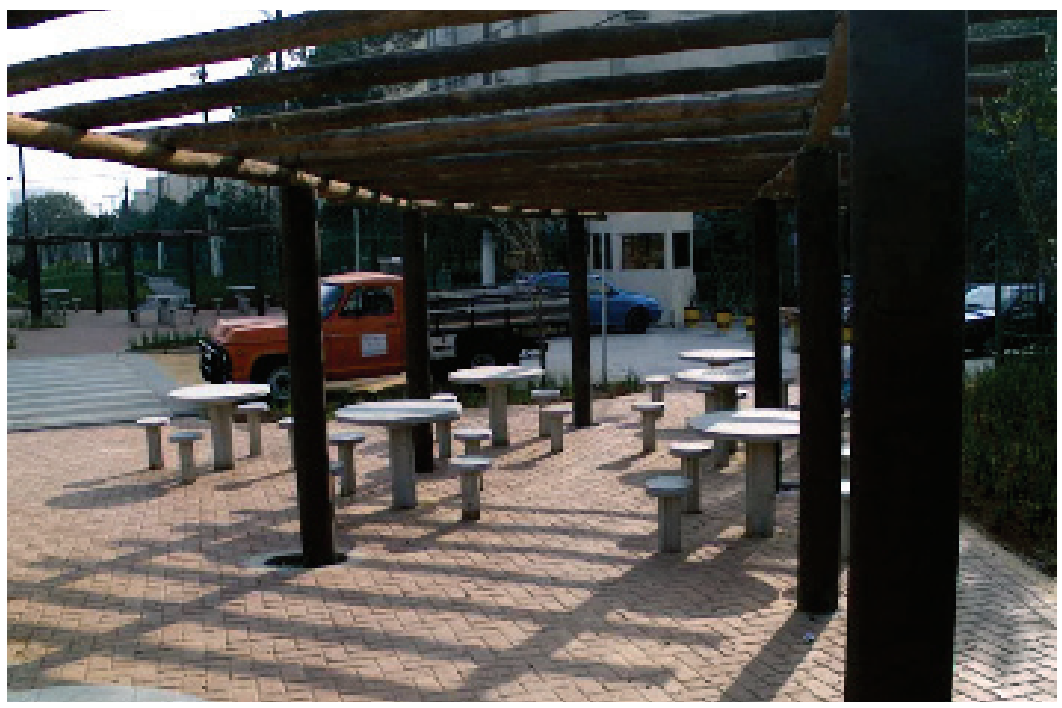

Equipamentos públicos

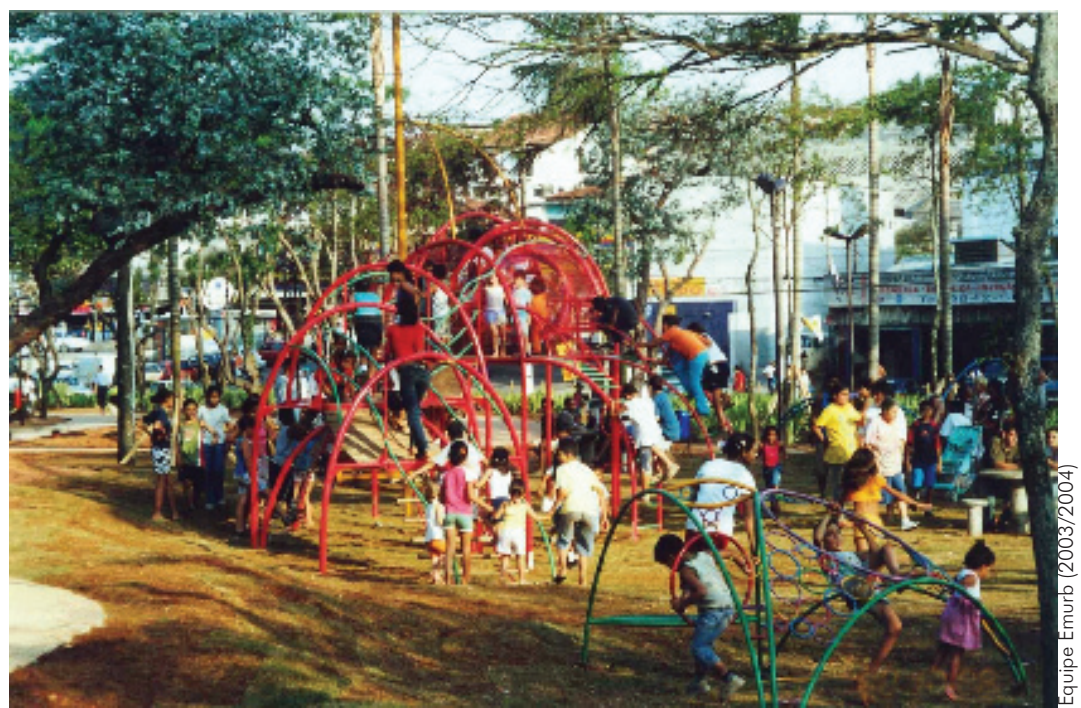




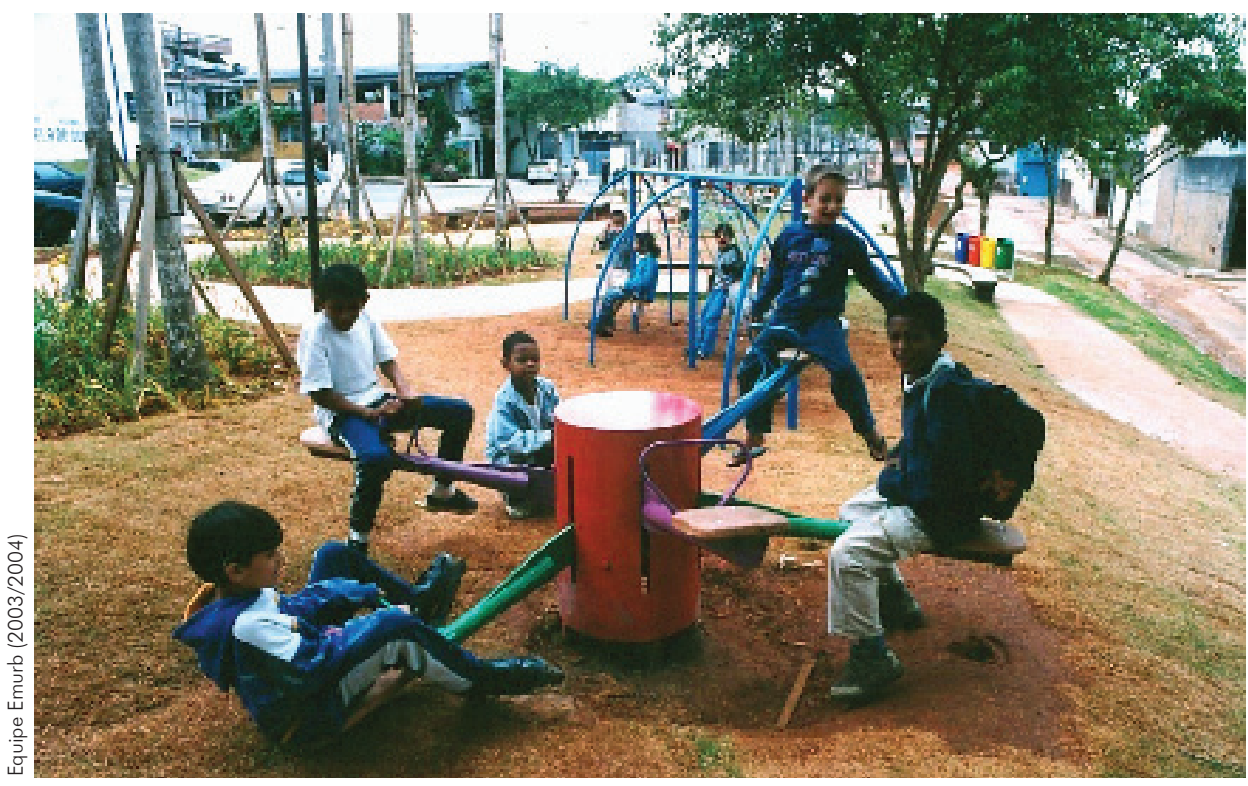

Equipamentos públicos Brinquedos (Projeto especial) Largo Campo Limpo

Milton Santos, no livro A natureza do espaço (2002), desenvolve a noção da indissociabilidade de sistemas de objetos, como produto social, e de sistema de ações na geografia. Na página 63, afirma: "Sistemas de objetos e sistemas de ações interagem. De um lado, o sistema de objetos condiciona a forma como se dão as ações e, de outro lado, o sistema de ações leva à criação de objetos novos ou se realiza sobre objetos preexistentes. É assim que o espaço encontra a sua dinâmica e se transforma."

Transportar essa noção para projetos em espaços públicos, com usos intensivos e apropriações diversas, apurando o olhar percuciente e não-dogmático, pode oferecer-nos surpresas e ensinamentos. Naturalmente, nenhum projeto se basta e sua riqueza pode residir, precisamente, nas dobras e fendas imprevistas.

\section{Paisagismo}

Objetivos do programa:

- relevância sígnica;

- ampliação de áreas drenantes;

- diminuição de ilhas de calor;

- enriquecimento da biodiversidade.

Acreditamos que as atuais cidades, com suas enormes carências de todos os tipos (saúde, educação, transporte) não podem, a despeito destas, prescindir e deixar de atentar, como paradigma de sua reconstrução sistemática, para a questão ambiental e paisagística.

projeto paisagístico, em sua amplitude de intervenção, não deve ser uma possibilidade (fruto do desinteresse, ignorância ou precariedade de verbas), 

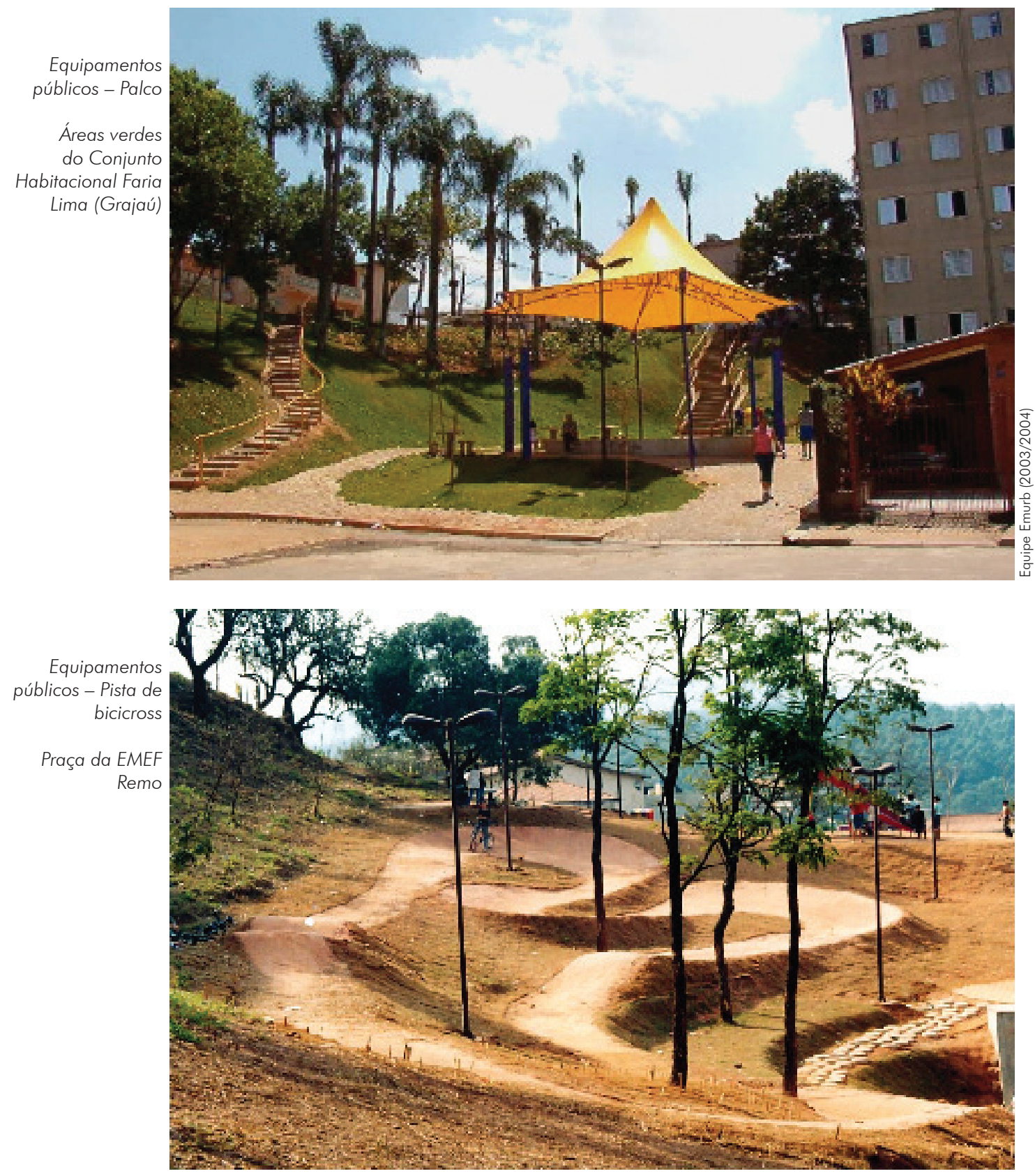

mas uma necessidade vital para o futuro das cidades, como local digno de vivência, moradia e trabalho, como "lugar de cidadania", com espaços públicos democratizados e qualificados.

Não se pode também ignorar que, a par da efetiva melhoria ambiental (redução de ilhas de calor, favorecimento da microdrenagem, entre outros), os projetos paisagísticos pensados na escala urbana possuem grande importância sígnica, como marcos visuais simbólicos, e, em determinadas circunstâncias, quase-icônicos. 


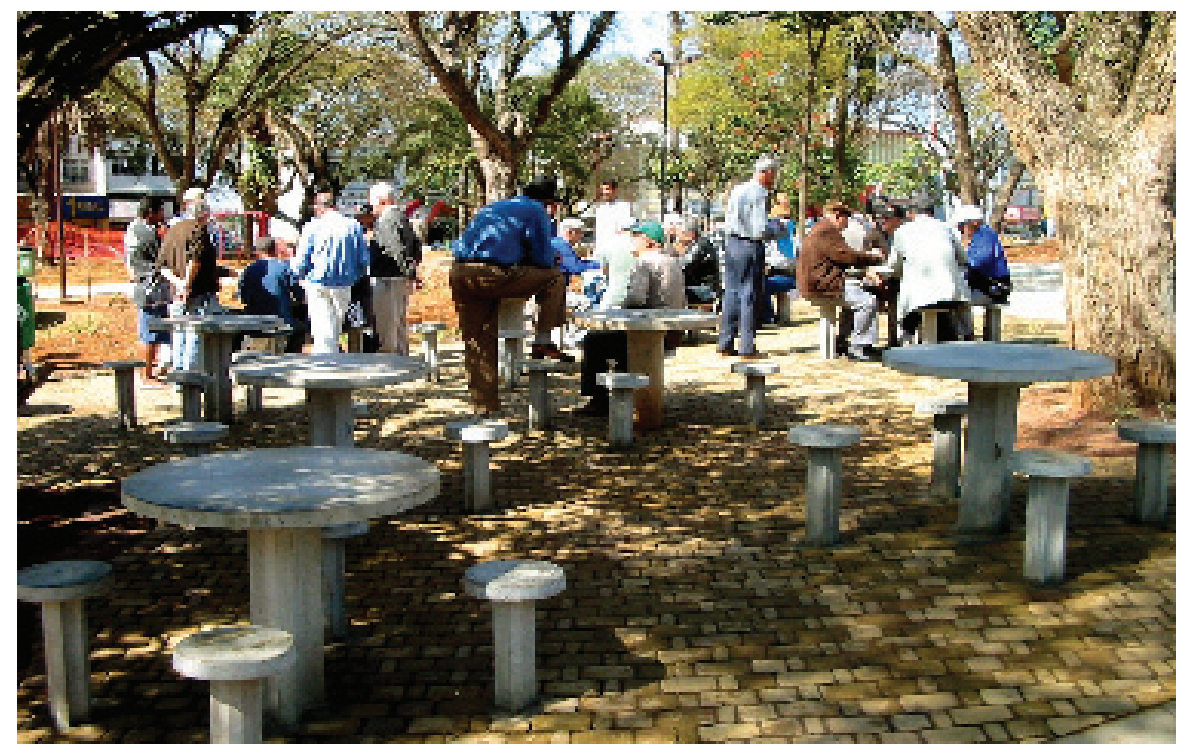

Praça Sampaio

Vidal - Aricanduva

Praça Sampaio

Vidal - Aricanduva

(Depois)

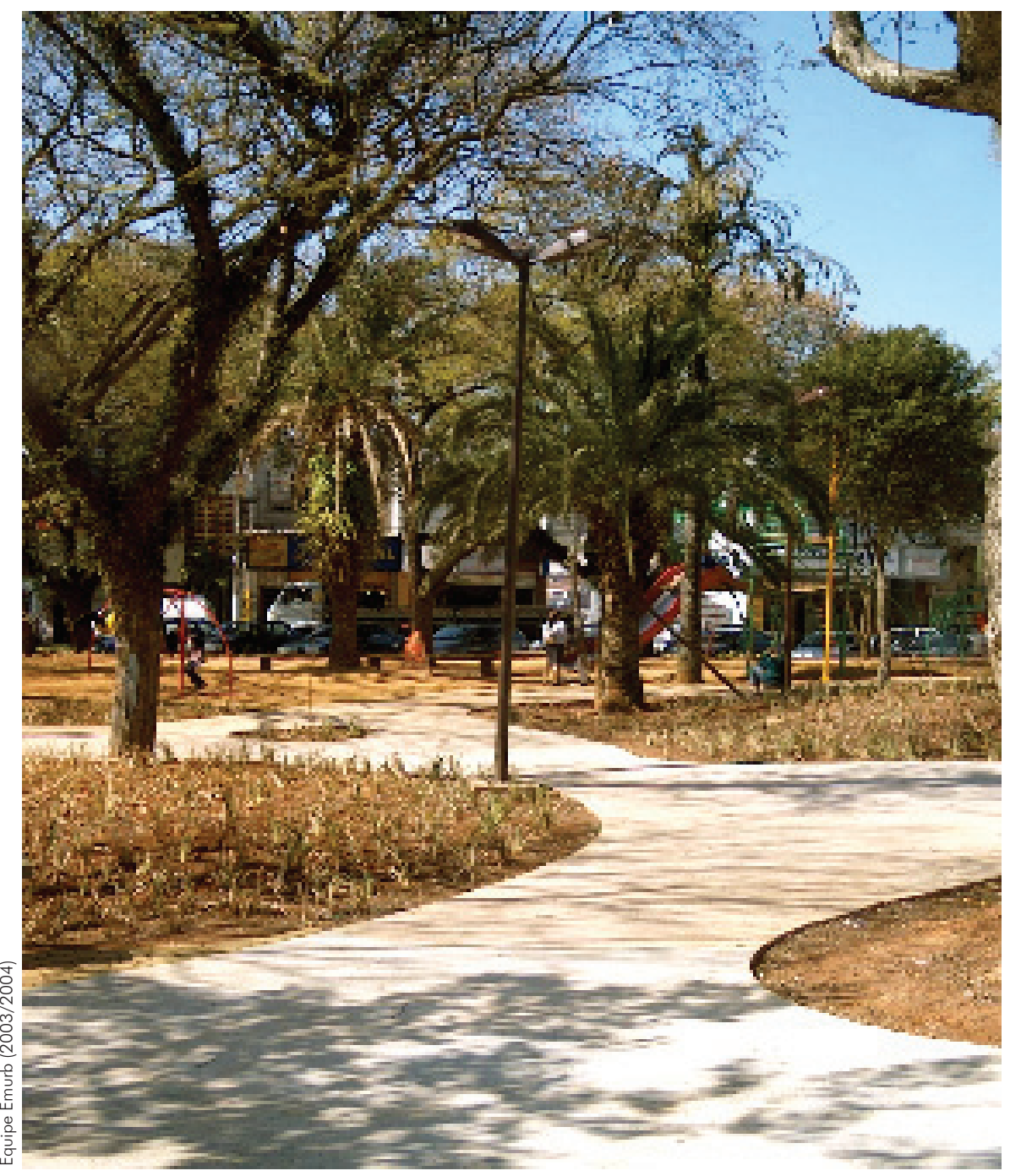



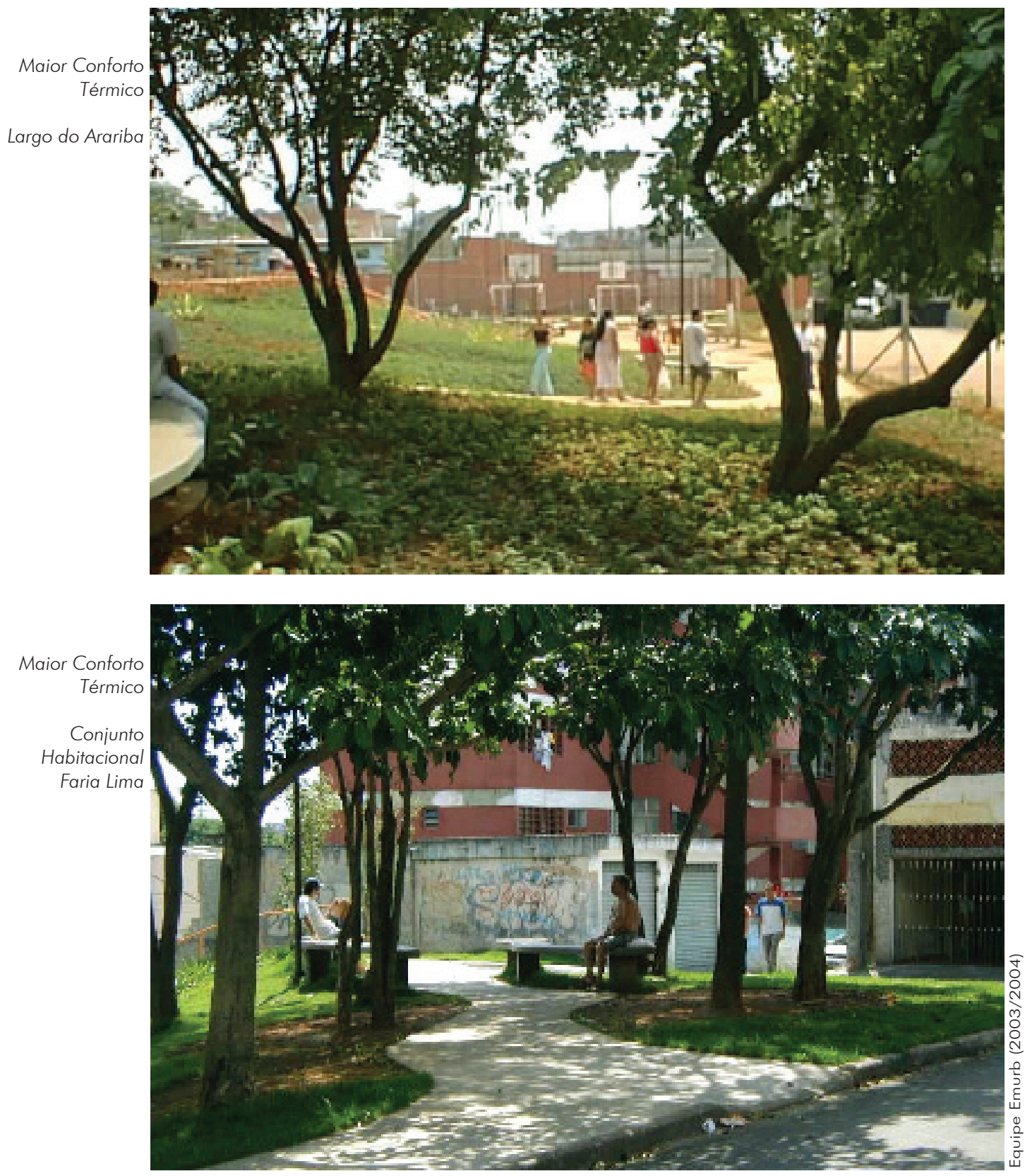

Em Pindorama revisitada (2000), Nicolau Sevcenko afirma: "O problema para - Brasil que se põe é claro - superar as mazelas legadas pela colonização e o escravismo. O que significa redistribuição de recursos e oportunidades, participação, cidadania plena, transparência no trato da coisa pública, estímulo ao desenvolvimento econômico, científico e tecnológico autônomo e preservação das condições ambientais."

Para o autor trata-se de um projeto de nação e, portanto, coletivo, que "requer um fundamento simbólico que una, motive e inspire seus participantes". Para ele, dísticos, imagens e músicas não incorporam o elemento decisivo 
da consciência temporal. E ele não pretende um monumento estático (e sim extático), faraônico, mas um marco afeito à escala humana. Propõe "algo simples, belo e mágico como um jardim tropical". Da palavra pindorama ele chega ao jardim de buritis: "um círculo de 100 buritis, um para cada ano do século XXI, definindo os limites do perímetro do parque - jardim".

Essa referência objetiva salientar a importância na paisagem urbana, muitas vezes carregada de informações caóticas e desconexas, do projeto paisagístico como organizador do olhar, como símbolo e referência local, índices espaciais, além, naturalmente, dos benefícios ao meio ambiente, bem como o embelezamento que os jardins proporcionam.

A importância do projeto paisagístico articulado na escala da cidade, ocorrido no município vizinho de Santo André, nas últimas duas gestões, sob coordenação do Departamento de Parques e Áreas Verdes local, forneceu parâmetros para o programa paulistano. A população daquele município tomou as intervenções paisagísticas como ganho urbano de qualidade de vida, e incorporou a nova paisagem como referência. Pesquisas indicam com absoluta precisão a urgência e emergência do paisagismo paradigmático. Em São Paulo, também há pesquisas que apontam a efetiva compreensão da importância de áreas verdes com forte presença sígnica.

Respeitando as proporções diversas entre os dois municípios e suas realidades, procurou-se introduzir alguns desses elementos compositivos (verticalidades pronunciadas, manchas de espécies arbóreas, especificação e valorização de espécies raras), bem como, caso a caso, cuidamos de focar as preocupações ambientais iniciais.

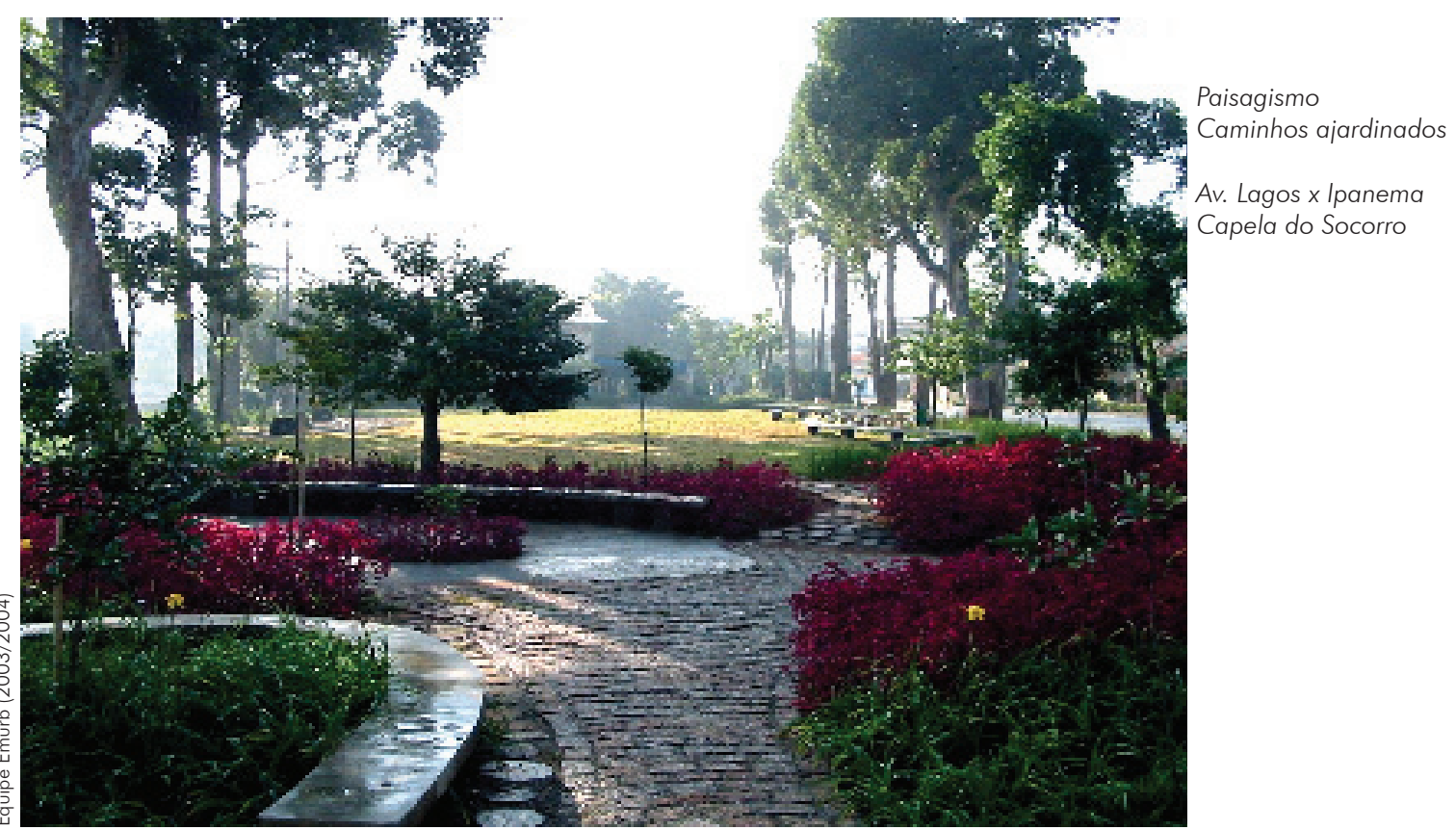


Paisagismo Caminhos ajardinados

Santo Dias Campo Limpo

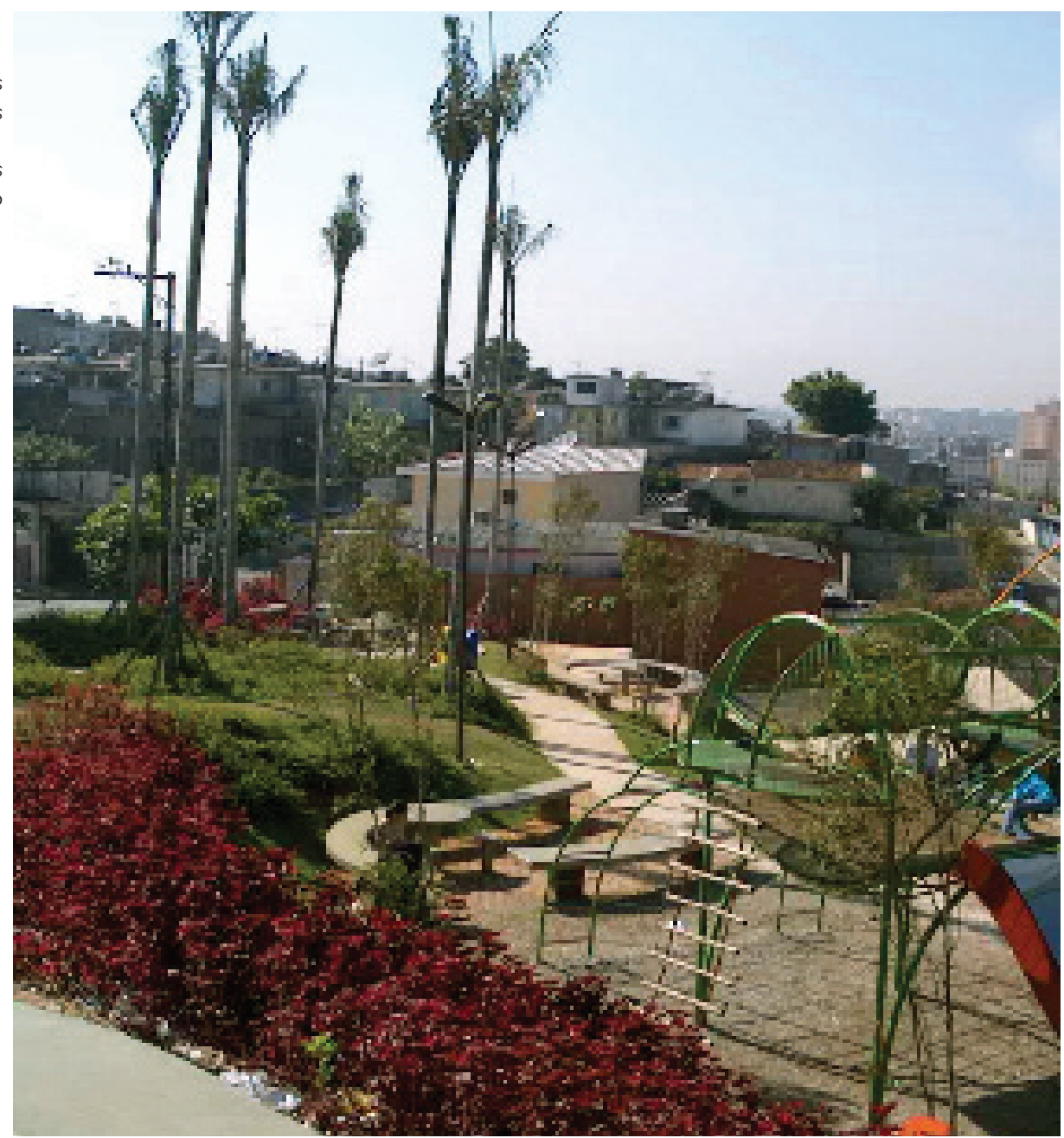

Maior segurança para pedestres - Passeios afastados da guia

Av. Armando de Arruda Pereira

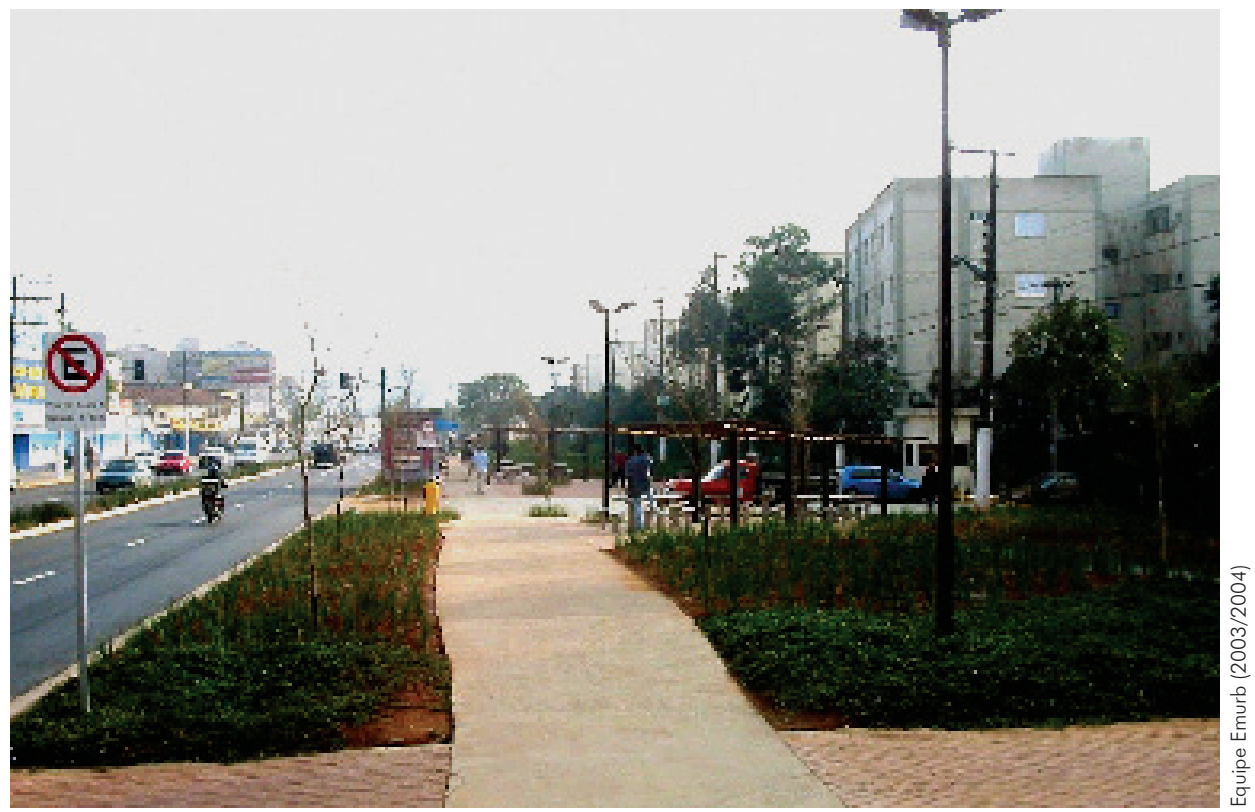


Um objetivo permanente desses projetos foi a ampliação das áreas permeabilizadas (cerca de $70 \%$ de toda a área de ação), contribuindo com a microdrenagem, com bacias naturais de captação de água, com a preservação de bordas e margens dos córregos com vegetação adequada. O próprio desenho dos pisos e suas inclinações procuram favorecer essa disposição.

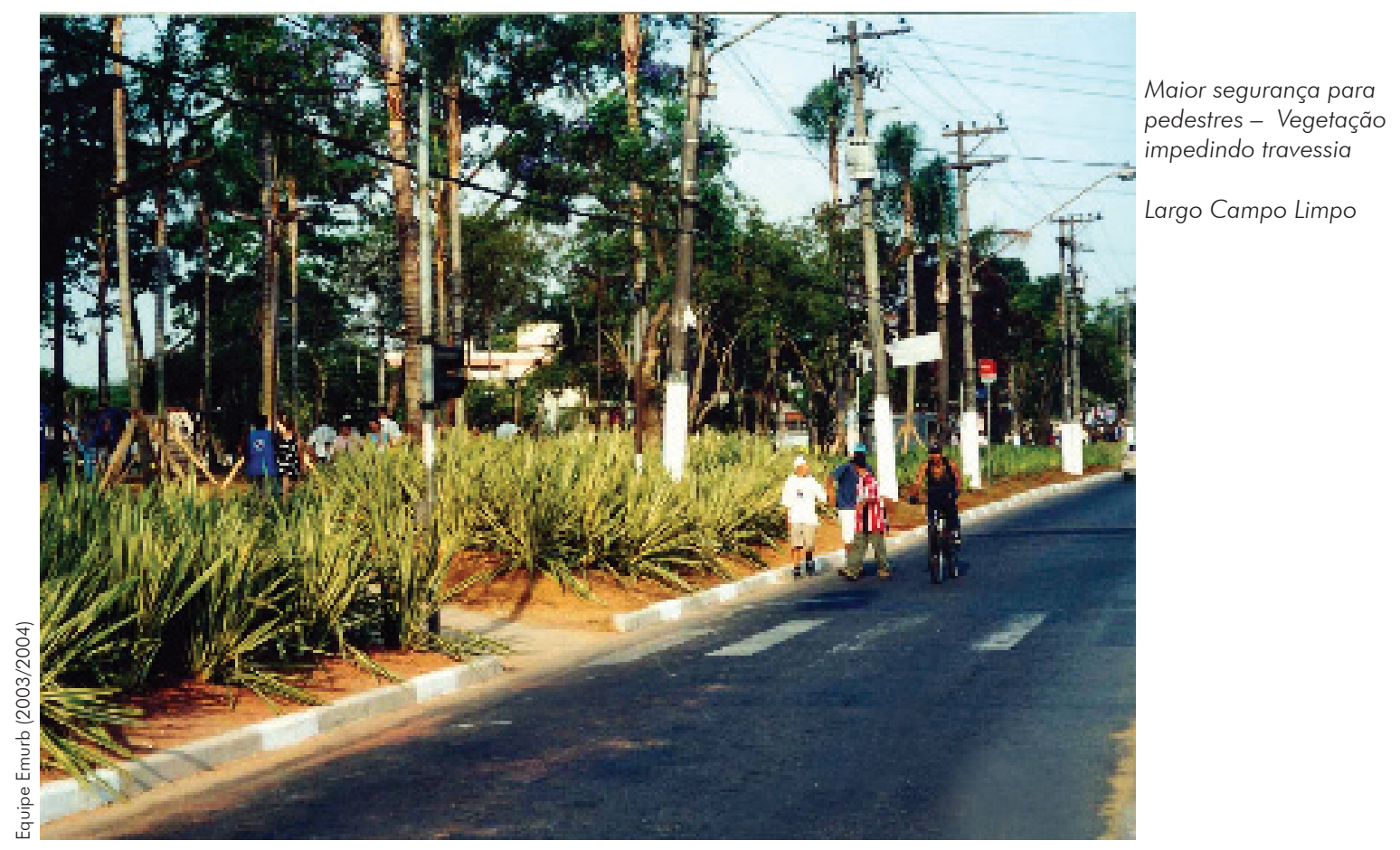

Outro elemento norteador das ações foi a ampliação da biodiversidade, já afirmada, como fator de qualidade da vida urbana. Esse aspecto característico desses projetos paisagísticos implantados alerta para a necessidade do estabelecimento de posturas culturais multiplicadoras, a despeito das dificuldades concretas para sua consecução.

A organicidade dos desenhos (da vegetação e, mesmo, dos pisos e equipamentos) ressalta a predominância das cores e valoriza os volumes proporcionados pelas espécies arbustivas e forrações utilizadas, formando panos entrecortados pelos passeios com texturas variadas. A contraposição com os volumes das copas das árvores, suas floradas, e também com as estruturas verticais reforçadas por transplantes de árvores e palmeiras adultas, pretende ser harmoniosa, constituindo-se em referência visual e, por que não, cultural.

A pauta ambiental foi particularmente importante. Quando sobrevieram oportunidades, como no Jardim Ângela e na Vila Maria, foram consideradas as nascentes existentes para a construção de lagos e, nestes casos, o elemento água agregou componentes (térmicos e táteis) enriquecedores do projeto. Em particular na Vila Maria, na praça das Nascentes, foi incorporado o elemento 
pedra de maneira criativa, por meio do trabalho da artista plástica Amélia Toledo, mimetizando animais se arrastando em busca de água, servindo, ao mesmo tempo, de banco ou objeto plástico autônomo.

Um item a destacar, importante para quem constrói obras públicas, é o rigor técnico exigido em memorial descritivo para o plantio das mudas e, principalmente, para os transplantes de espécies adultas. Foram incansavelmente fiscalizadas dimensões de covas, qualidade de adubação, alturas de mudas, DAPs (Diâmetro à Altura do Peito), torrões adequados, procedimentos técnicos e ferramentas. Foram criadas tabelas e documentação as quais dessem conta dessa tarefa, amparadas legalmente, e exigindo-se que fossem obedecidas as especificações.

Praça das Nascentes
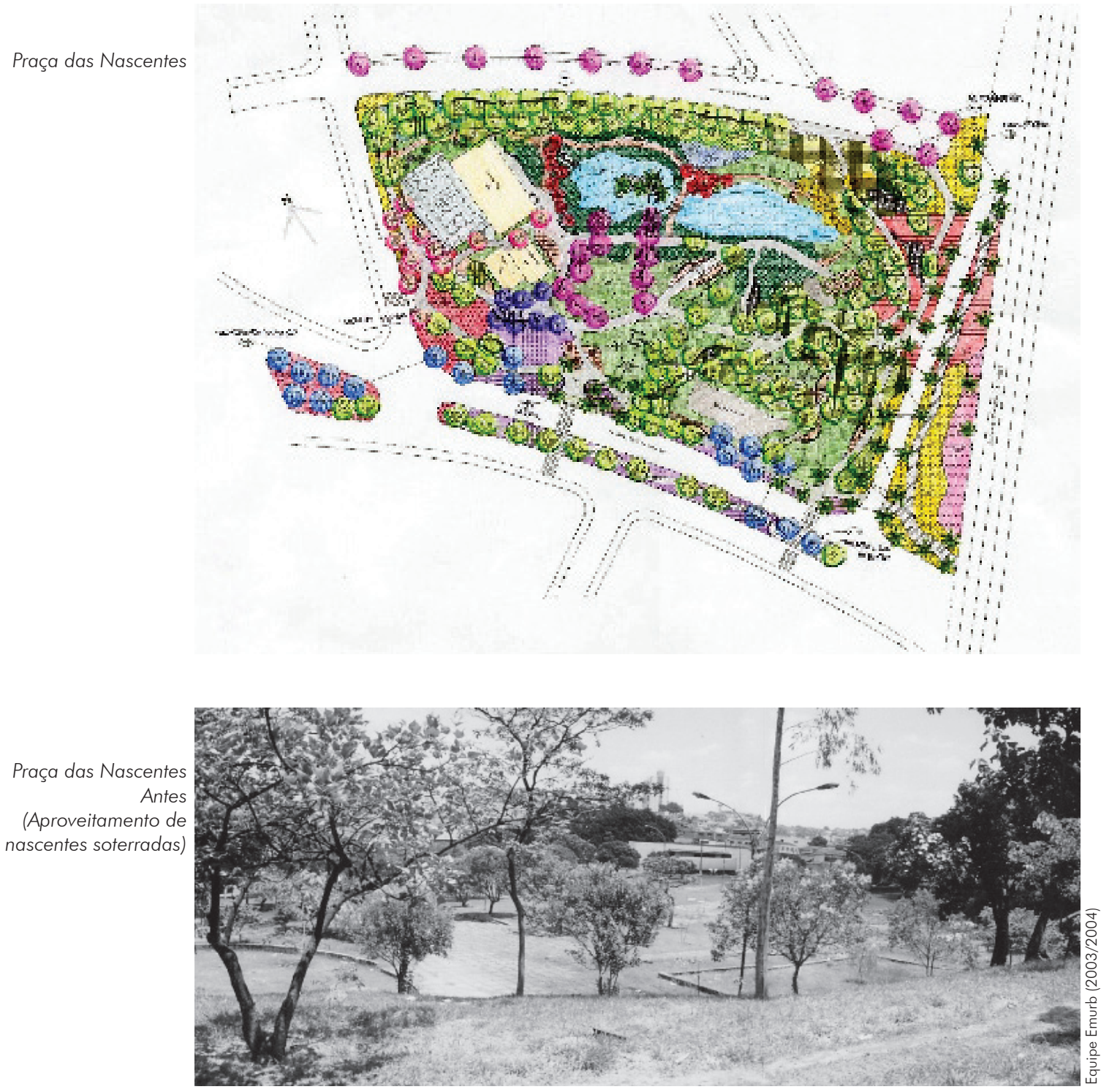


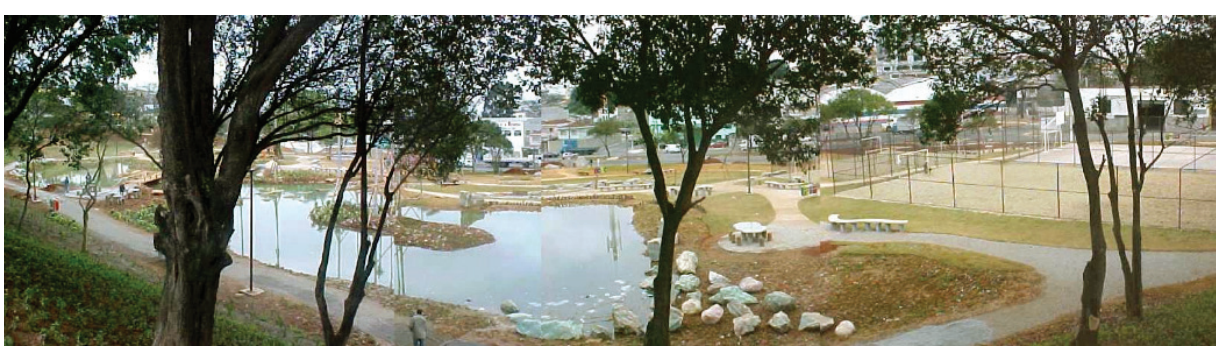

Depois

Lago, áreas verdes e estares
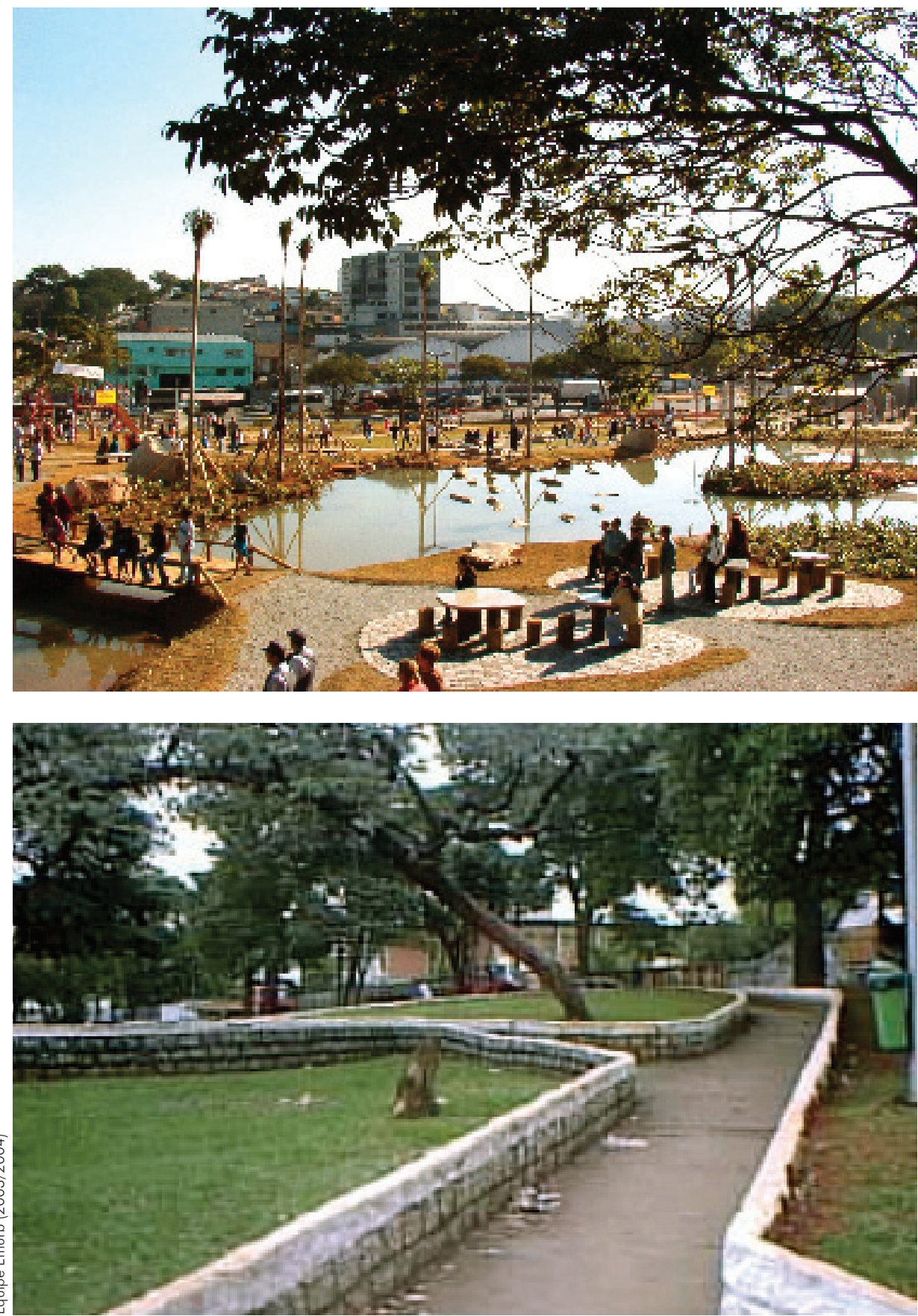

Antes

Largo do Campo

Limpo

Campo Limpo 


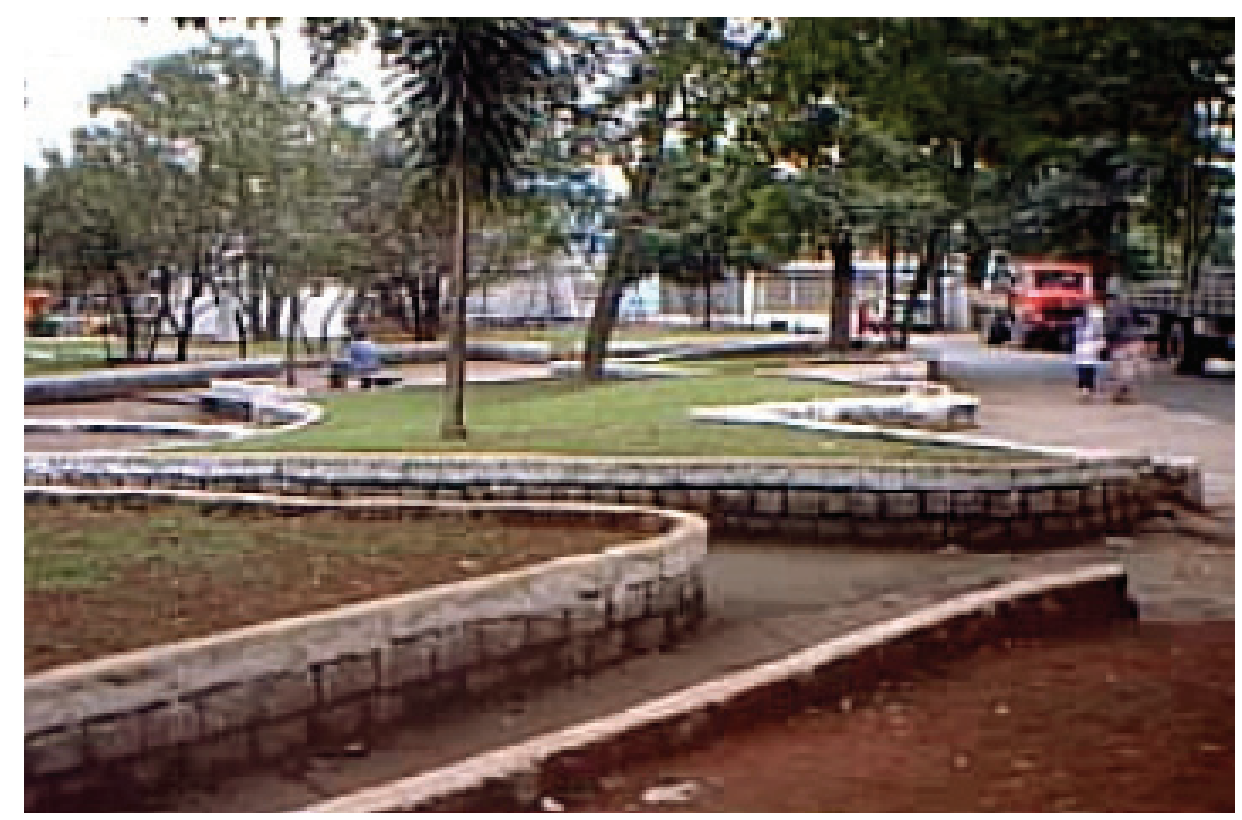

O paisagismo público exige cuidados especiais na escolha e definição das espécies a serem utilizadas. A necessidade de baixa manutenção implica no uso de espécies rústicas, e seu desenho deve valorizar claramente essas espécies, com suas floradas e formas. O usuário passa entre a vegetação, senta-se no meio de cores visíveis. No Centro de Bairro do Campo Limpo foram construídos bancos curvos de concreto circundando três grandes "pausferro" existentes com plantio de "lírios-da-paz" na área circunscrita. Tornou-se uma área de estar extremamente popular. Cheiros, volumes, formas ao vento têm de ser considerados na escala das áreas e seu entorno.

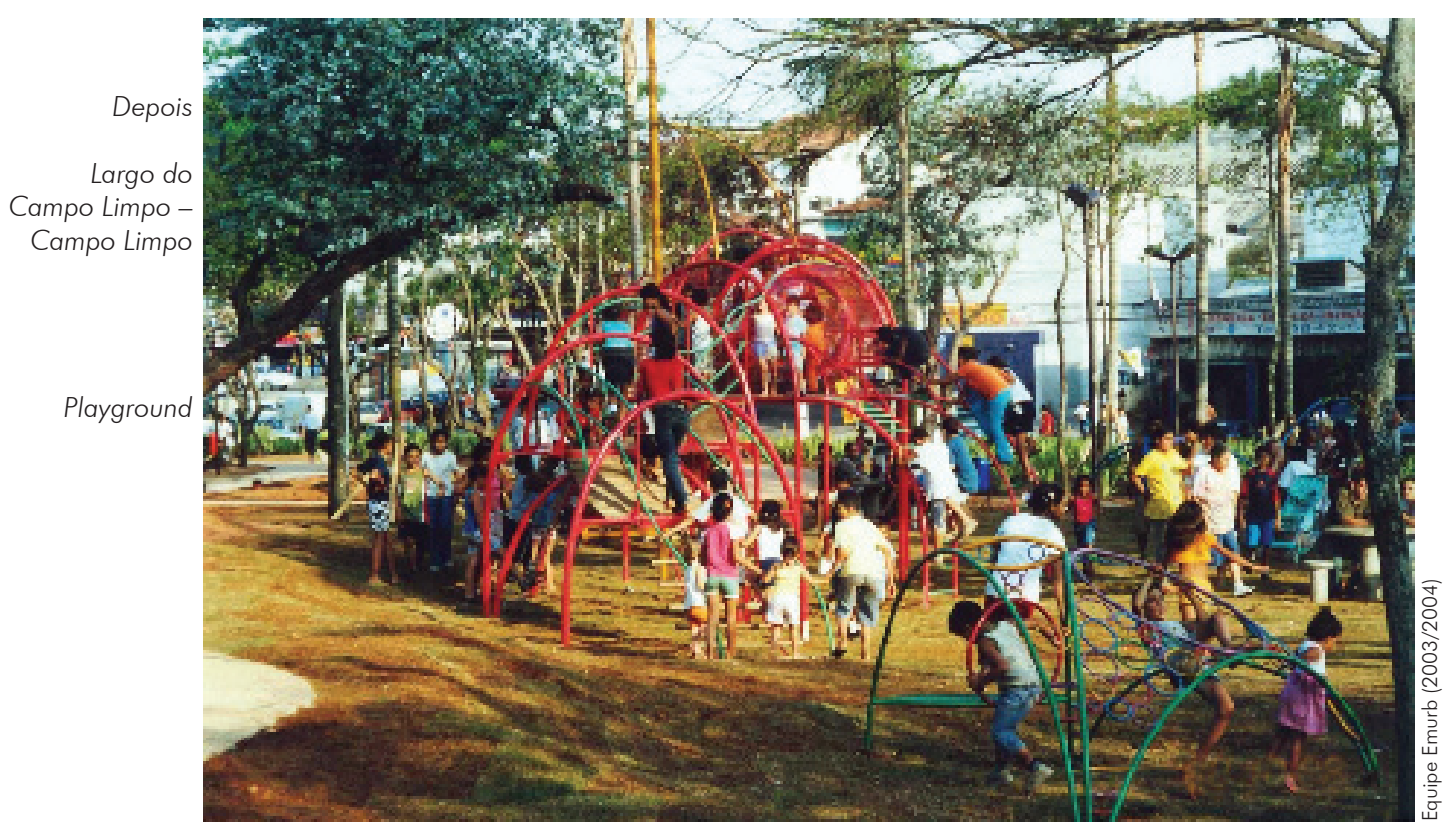




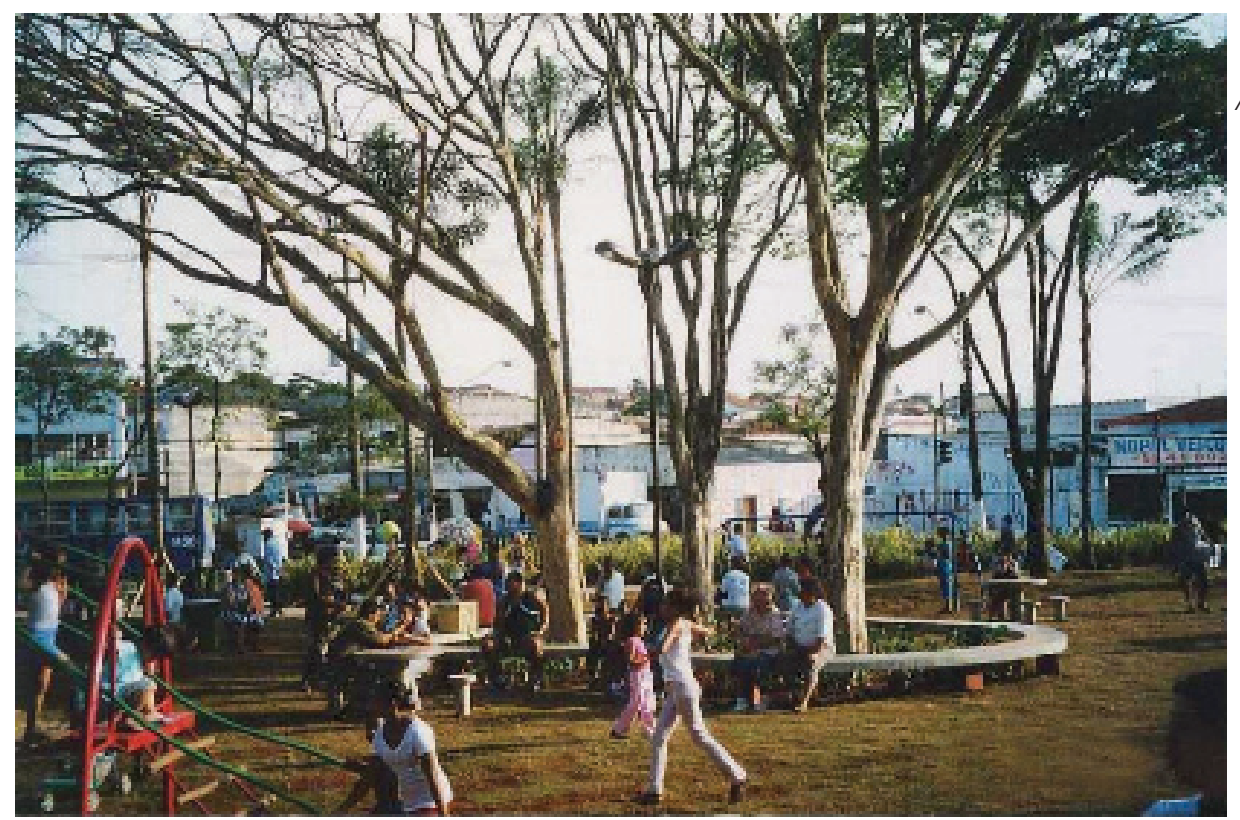

Área de Estar

O futuro das cidades democráticas, sua habitabilidade, seus planejamentos dependem da incorporação de valores e práticas ambientais. O paradigma ambiental e paisagístico torna-se crucial, se pensarmos as estruturas e redes que as compõem. O que fazer com as águas? Com as ilhas de calor? Com os resíduos sólidos? Há muito a fazer, um vastíssimo campo a atravessar. De qualquer forma, positivamente, foram realizadas experiências e diálogos bastante profícuos e satisfatórios com os construtores urbanos. Operadores e projetistas da malha viária, na cidade de São Paulo, têm dedicado especial

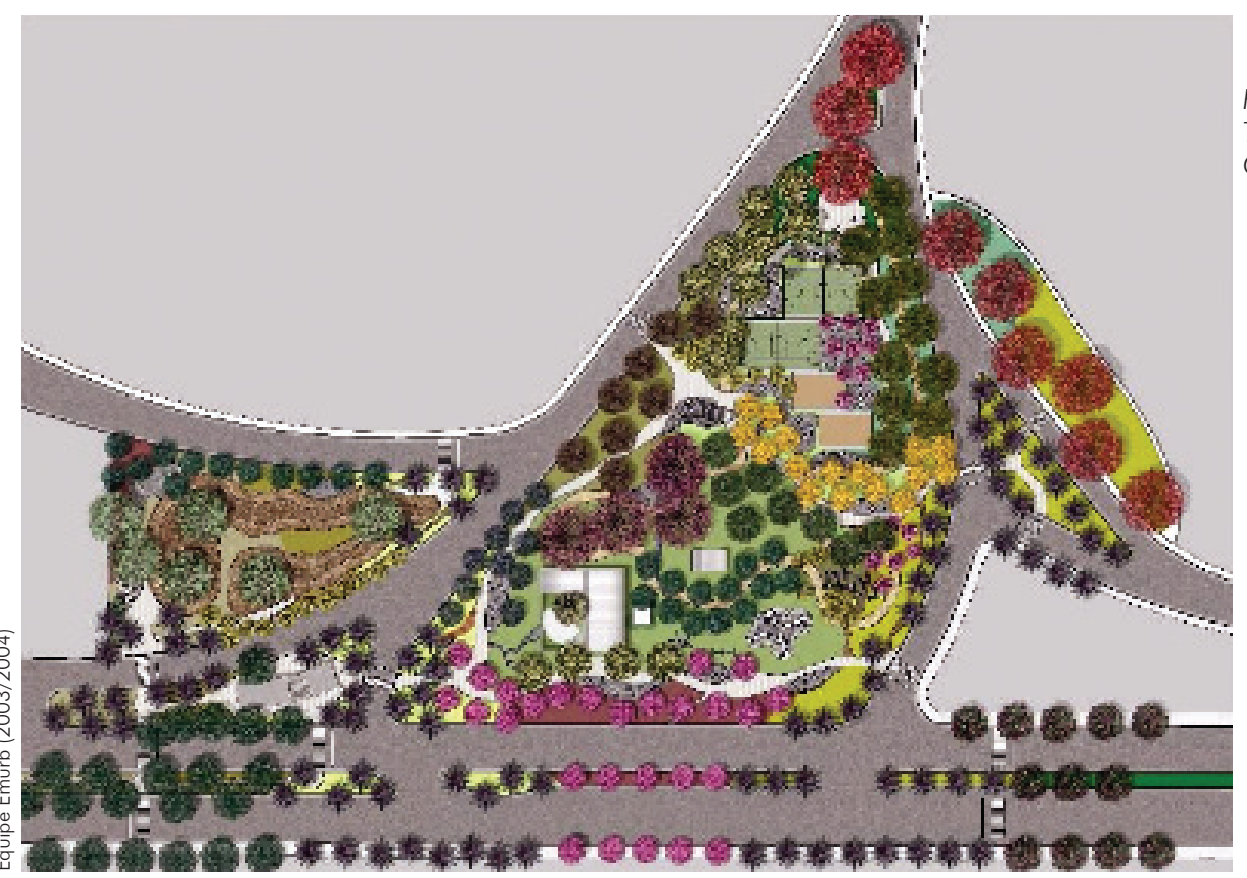

Praça do

Trabalhador

Capela do Socorro 
atenção para a necessidade de áreas verdes de qualidade, e seus projetos têm refletido esse tópico. Os corredores viários, em obras (2004), têm sido acompanhados de intervenções paisagísticas.

Estamos em um momento particularmente propício para a consolidação dessas urgências, podendo os projetos paisagísticos e a questão ambiental se tornarem referência qualitativa e preocupação real no planejamento urbano e nas ações dos governos nas várias esferas.

Especial cuidado e atenção procuramos ter com a manutenção das áreas ajardinadas. É corrente que a dificuldade e a precariedade dessa manutenção (despraguejamento, limpeza, replantio, irrigação permanente em épocas de estiagem) seja fator de desânimo, levando à desistência da elaboração de projetos. É necessário reverter essa lógica arraigada e recorrente.

Não se pode aguardar o estabelecimento de políticas apropriadas de manutenção. Em verdade, a própria existência desses espaços gerou a necessidade de criá-las, formando-se, nesse momento, equipes de manutenção específicas para essas áreas, para em seguida estendê-las ao restante das áreas ajardinadas.

\section{Matrizes}

Considerando-se as características topográficas, dos entornos e de uso das 50 áreas foi possível, para efeito prático e de sistematização, o estabelecimento de "matrizes de projetos". Pode, inclusive, ocorrer de uma área "conter" mais de uma matriz, ou ainda, de uma matriz gerar submatrizes, conforme segue:

1. Miniparques de vizinhança: Praça do Trabalhador (zona sul), praça das Nascentes (zona norte), Feirão do São Luiz (zona sul), City Jaraguá (zona norte).

2. Ao longo de avenidas: Av. Armando Arruda Pereira (zona sul), entorno do Cemitério de Vila Nova Cachoeirinha (zona norte).

3. Baixos de viadutos: Entorno do Mercado Municipal de Guaianazes (zona leste), entrada de São Miguel (zona leste).

4. Declividade acentuada: EMEF Remo (zona norte), praça Santos Dias da Silva (zona sul).

5. Rotatórias: Largo de São Mateus (zona leste), praça Padre Damião (zona leste), Largo do Japonês (zona norte).

6. Em escolas: Praça Wilson Moreira da Costa (zona oeste), praça João

Boldo (zona norte), praça Santíssima Trindade (zona norte), Largo do Arariba (zona sul). 
7. Em córregos/rios: Av. Ipanema c/ Av. Lagos (zona sul), praça João Amazonas em Ermelino Matarazzo (zona leste), praça Jardim Cabuçu (zona norte).

8. Em conjuntos habitacionais: Conjunto Habitacional Faria Lima, no Grajaú (zona sul), conjunto habitacional na Cidade Tiradentes (zona leste), praça no Jaçanã (zona norte).

Uma análise mais detida desses projetos pode demonstrar que essa sistematização reflete as naturais influências do meio nos trabalhos de um programa bastante amplo. A experimentação, a apropriação e o uso desses espaços devem confirmar e conformar este e novos agenciamentos. Verificação e aprendizado, com olhos abertos, de ver e prever, são tarefas necessárias para outros rearranjos, para inevitáveis ajustes e correções.

"As cidades são, por definição, o espaço para a construção da cidadania, para o convívio harmonioso e fértil das diferenças, assim como para a celebração da liberdade e das fantasias." SEVCENKO, Nicolau (2000).

\section{Programa Centralidades Urbanas}

\section{Equipe Técnica}

Sérgio Marin de Oliveira - Arquiteto/gerente

José Carlos Perdigão - Engenheiro agrônomo/coordenador

Ana Paula Felippe - Arquiteta

Bernadete Faria - Engenheira agrônoma

Cristina Fischett Bonecker - Arquiteta

Daniel Larrabure Meirelles - Arquiteto

Eduardo Sales de Oliveira - Engenheiro agrônomo

Edimilson Peres Castilho - Arquiteto

Herbert Silva Ortiz - Arquiteto

José Eduardo de Sousa Costa - Engenheiro agrônomo

Karla Lopes Blanco Alvarez - Arquiteta

Paulo Barreiros de Oliveira - Arquiteto

Radomir Tomitch - Engenheiro agrônomo

Renato de Oliveira Laiza - Arquiteto 


\section{Bibliografia}

ALMEIDA, Elvira de. Arte lúdica. São Paulo: Edusp, 1997.

CHACEL, Fernando. Paisagismo e ecogênese. Rio de Janeiro: Ed. Fraiha, 2000.

FERRARA, Lucrécia D’Alessio. A estratégia dos signos. São Paulo: Perspectiva, 1981.

LIMA, Mayumi Souza Lima. A cidade e a criança. São Paulo: Nobel, 1989.

ORLANDI, Eni P. Cidade atravessada: Os sentidos públicos no espaço urbano. São Paulo: Pontes Edisons, 2001.

SANTOS, Milton. A natureza do espaço. São Paulo: Edusp, 2002.

SEGAWA, Hugo. Ao amor do público - Jardins no Brasil. São Paulo: Nobel, 1996.

SEVCENKO, Nicolau. Pindorama revisitada: Cultura e sociedade em tempos de virada. São Paulo: Peirópolis, 2000. 